\title{
PERAN SERTA DAN MEKANISME BANK SYARIAH PADA PEMBIAYAAN SINDIKASI DI BANK SYARIAH MANDIRI PUSAT
}

\section{PARTICIPATION AND FINANCING MECHANISM ISLAMIC BANK ON SYNDICATION STUDIES IN SYARIAH MANDIRI BANK CENTRE}

\author{
Mardiana Yose ${ }^{1 a} ;$ Rully Trihantana ${ }^{2}$ \\ 1aProgram Studi Perbankan Syariah Fakultas Ekonomi Islam Universitas Djuanda, Jl. Tol \\ Ciawi No. 1, Kotak Pos 35 Bogor 16720. \\ 2Program Studi Perbankan Syariah Fakultas Ekonomi Islam Universitas Djuanda, Jl. Tol \\ Ciawi No. 1, Kotak Pos 35 Bogor 16720.
}

(Diterima oleh Dewan Redaksi 29-09-2017)

(Dipublikasikan oleh Dewan Redaksi 18-12-2017)

\begin{abstract}
The purpose of this study to determine the role of Islamic banks in the syndicated financing as well as knowing how syndication mechanism in BSM. The method used is descriptive qualitative. Primary data in this study of related documents syndicated financing, secondary data in the form of information obtained from the Internet, books, journals, articles, and other literature. Based on the results of the study, it was concluded that the role of Islamic banks in the syndicated financing not only to increase Islamic banking assets only, but to maintain liquidity and to contribute to the national development in Indonesia. This requires improving prudential banking Islamic banks to provide syndicated financing by implementing a syndication mechanism with in-depth analysis process so that funding channeled can return safely.
\end{abstract}

Keywords: Participation, Mechanism, Sharia Bank, Syndication, Financing

\begin{abstract}
ABSTRAK
Tujuan penelitian ini untuk mengetahui peranan bank syariah pada pembiayaan sindikasi serta mengetahui bagaimana mekanisme sindikasi di BSM. Metode yang digunakan yaitu deskriptif kualitatif. Data primer pada penelitian ini berupa dokumendokumen terkait pembiayaan sindikasi, sedangkan untuk data sekunder berupa informasi yang diperoleh dari internet, buku, jurnal, artikel, dan literatur lainnya. Berdasarkan hasil penelitian, disimpulkan bahwa peran serta bank syariah pada pembiayaan sindikasi tidak hanya untuk meningkatkan asset perbankan syariah saja, melainkan untuk menjaga likuiditas dan ikut berkontribusi dalam pembangunan nasional di Indonesia. Hal tersebut mengharuskan bank syariah meningkatkan prudential banking dalam memberikan pembiayaan sindikasi dengan cara menerapkan mekanisme sindikasi dengan proses analisa yang mendalam agar pembiayaan yang disalurkan dapat kembali dengan aman.
\end{abstract}

Kata Kunci : Peran Serta, Mekanisme, Bank Syariah, Sindikasi, Pembiayaan 
Mardiana. 2017. Peran Serta dan Mekanisme Bank Syariah Pada Pembiayaan Sindikasi di Bank Syariah Mandiri Pusat. Jurnal Nisbah 3 (2): 403 - 423

\section{PENDAHULUAN}

Meningkatnya perekonomian berbasis syariah saat ini, menandakan pertumbuhan sektor syariah semakin meningkat. Melalui pengenalan inovasi produk yang cukup beragam, salah satunya mengenai produk pembiayaan, dengan adanya fasilitas pembiayaan maka dapat membantu masyarakat untuk mensejahterakan hidupnya. Selanjutnya pemerintah Indonesia membuat perjanjian untuk bank syariah agar berkesempatan melebarkan sayap bisnisnya, serta menjadi bagian proses dari kesejahteraan masyarakat (Ascarya, 2012: 203-204).

Salah satu rencana perbankan dalam meningkatkan asetnya, yaitu dengan cara mengembangkan pembiayaan kedalam sektor korporasi. Namun, dengan dilakukannya pembiayaan korporasi maka akan menyebabkan timbulnya risiko yang besar pula (high risk high return), itu sebabnya bank syariah wajib melakukan sharing dana dan sharing risiko dengan bank lainnya (Ghoniyah, 2012: 52, Pratama, Dian, Budiharto, dan Nand, Sartika 2016: 2, Agustianto, 2016).

Penyebab mendasar atas terjadinya suatu risiko yakni bank terlalu memudahkan pencairan pembiayaan yang dibutuhkan nasabah, karena dituntut untuk memanfaatkan asset yang dimiliki bank, sehingga dapat terhindar dari adanya dana mengendap (idle fund), yang akibatnya akan mempengaruhi tingkat oprasional bank, dan akan menyebabkan penilaian terhadap calon nasabah kurang cermat. Hal tersebut menimbulkan kemacetan (gagal bayar) yang dilakukan nasabah dalam melaksanakan kewajibannya (Saputra, Arifin, Zahroh, 2015: 4).
Dalam pelaksanaan pembiayaan kepada sektor korporasi, bank syariah tak dapat mendanai satu proposal tertentu secara tunggal, melainkan harus bekerja sama oleh pihak (bank) lainnya. Sehingga akhirnya, perbankan syariah melebarkan sayapnya kedalam sektor korporasi dengan menggunakan pembiayaan sindikasi (Sholihin, 2010: 613).

Melalui sindikasi sebagai teknik dalam menyebarkan risiko, untuk meminimalisir adanya risiko pembiayaan. Dikarenakan melalui sindikasi maka risiko pembiayaan dapat ditanggung oleh para peserta sindikasi lainnya (Harmain, 2015: 104).

Dimana apabila terdapat kerjasama sindikasi sesama bank syariah akan menggunakan sistem bagi hasil, yaitu dengan melakukan profit and loss sharing, yang didalamnya menggunakan suatu konsep dimana dalam menghadapi kerugian dan dalam memperoleh keuntungan akan dilakukan secara bersama. Sedangkan apabila terdapat kerjasama sindikasi yang melibatkan bank syariah dengan bank konvensional, apabila sepanjang tidak melanggar dan bertentangan dengan prinsip syariah maka dapat dilakukan, selama terdapat pemisahan dan pembatasan terhadap aspek tertentu (Idris, 2015: 2, Karim, 2005: 4, Peristyanti, 2008, dan Agustianto, 2016).

Peran penting pembiayaan sindikasi bagi pertumbuhan perekonomian serta kesejahteraan masyarakat baik itu dalam segi infrastruktur, komersial maupun investasi adalah bentuk kontribusi secara langsung dalam meningkatkan pembangunan nasional. Karena sindikasi tidak hanya berfungsi guna 
meningkatkan aset saja, melainkan untuk membantu memenuhi usaha nasabah. Kehadiran pembiayaan sindikasi merupakan solusi terbaik untuk penyediaan dana yang besar dalam mengejar ketertinggalan utamanya dibidang pembangunan (Agustianto, 2016, Sumual, 2016: 103).

Manifestasi bank selaku agen pembangunan terutama peranannya dalam meningkatkan pembangunan, mengingat secara nasional aspek pembiayaan masih sangat menentukan volume pertumbuhan ekonomi nasional secara keseluruhan, dan suatu pembiayaan mencapai fungsinya apabila secara sosial ekonomis membawa pengaruh positif bagi semua pihak (Arethusa, 2016: 2, Harimurti, 2012: 4).

Solusi terbaik bagi perbankan khususnya perbankan syariah dalam mengelola $\mathrm{BMPK} / 3 \mathrm{~L}$ dan menghindari adanya idle fund adalah menjadi peserta sindikasi yang menyediakan produkproduk korporasi sebagai alternatif demi menyempurnakan kepentingan pembiayaan skala besar, sekaligus rencana bank dalam meningkatkan pendapatannya karena kompetisi antar perbankan sudah semakin tajam. Sehingga menuntut bank syariah agar mengejar ketertinggalannya terhadap bank-bank konvensional (Kusumo, 2008: 110). Hal tersebut yang mendasari penulis untuk merumuskan pertanyaan penelitian yaitu:

1. Bagaimana peran serta BSM pada pembiayaan sindikasi.

2. Bagaimana mekanisme pembiayaan pindikasi pada BSM.

\section{MATERI DAN METODE}

\section{Bank Umum Syariah (BUS)}

BUS merupakan jasa keuangan yang sangat bergantung terhadap kepercayaan masyarakat dalam mengelola asetnya. Untuk memastikan agar arus dana dapat berjalan sebagaimana yang sudah direncanakan, sehingga mismatch antara surplus unit dengan deficit unit tidak akan terjadi. Seiring dengan berkembangnya bank syariah, maka perkembangan BUS pun semakin baik (Kasmir, 2013: 5, Ascarya, 2012: 2 dan Iska, 2012: 19).

\section{Corporate Banking Group (CBG)}

$C B G$ merupakan divisi atau bagian yang memfokuskan pelayanan dan transaksinya kepada nasabah-nasabah yang berskala besar atau corporate. Namun $C B G$ tidak hanya memfasilitasi nasabah corporate yang berbentuk perusahaan saja, melainkan nasabah individual juga. Pelayanan individual diarahkan agar dapat bekerjasama lebih aktif dengan nasabah korporasi lainnya.

Peran dan fungsi corporate banking yaitu untuk membantu direksi dalam menangani tugas-tugasnya, khususnya menyangkut bidang pembiayaan dalam skala besar. Sedangkan tugas direktur corporate banking yaitu menerjemahkan visi, arah strategi perusahaan dan strategi bisnis, melaksanakan rencana kerja serta anggaran CBG berdasarkan break-down dari direksi, mengadakan hubungan dengan bidang serta instansi lain yang masih berkaitan dalam bidang corporate banking, mengambil berbagai kebijakan sebagai jaminan mengenai anggaran (Suhardjono, 2002: 117-118).

Terdapat bagian yang menangani pembiayaan korporasi, meskipun pada dasarnya Bank Indonesia (BI) tidak mengeluarkan peraturan khusus terkait struktur organisasi corporate banking. Namun dalam rangka pemisahan fungsi mengenai aktivitas/kegiatan mitigasi risiko, membuat bank syariah perlu memisahkan setiap divisi sesuai dengan peranannya.

Terdapat tiga unit dalam perbankan syariah yaitu unit risk, unit bisnis, dan unit support. Penanganan pembiayaan korporasi dan sindikasi akan ditangani oleh unit bisnis, dimana terdapat tujuh 
unit bisnis didalamnya yaitu unit bisnis Finance \& Strategy, unit bisnis Risk Management \& Compliance, unit bisnis Technology \& Operation, unit bisnis Finance Risk \& Recovery, unit bisnis Distribution \& Service, unit bisnis Retail Banking dan unit bisnis Wholesale Banking. Khusus pembiayaan korporasi masuk ke dalam unit bisnis wholesale banking, dimana terdapat enam divisi, yaitu:

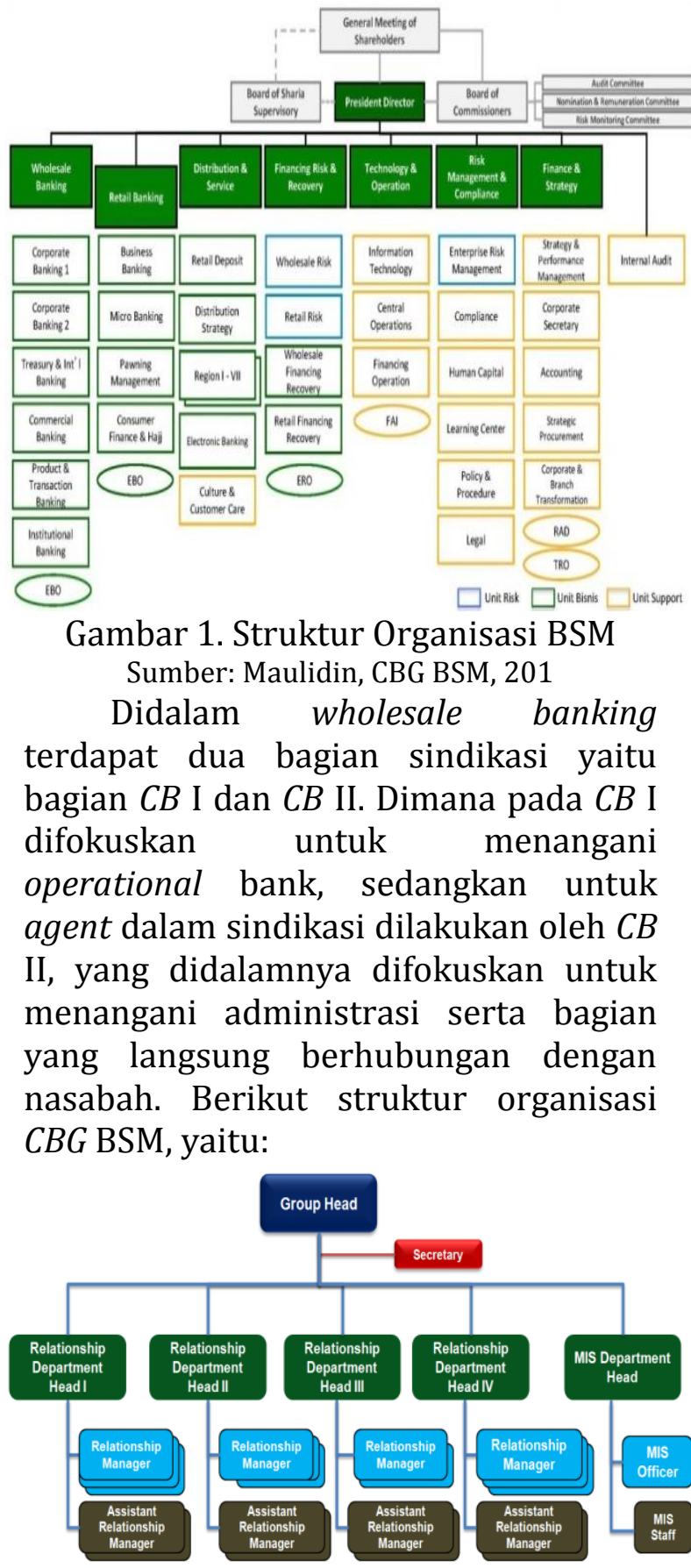

Gambar 2. Struktur Organisasi $C B G$ I Sumber: Maulidin, CBG BSM, 2017

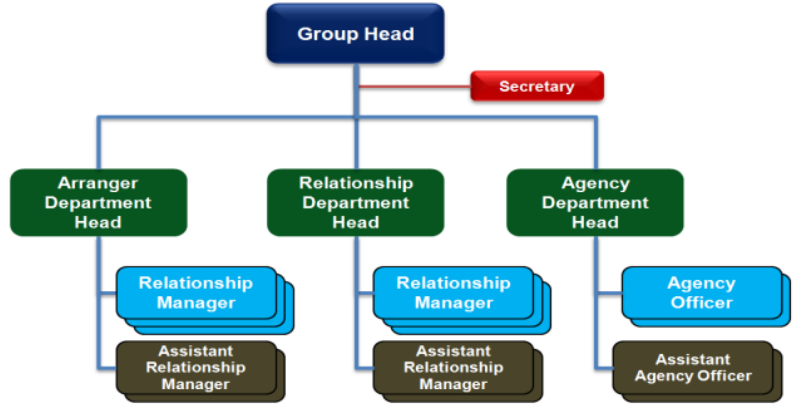

Gambar 3. Struktur Organisasi $C B G$ II Sumber: Maulidin, CBG BSM, 2017

\section{Pembiayaan Korporasi (Corporate Financing)}

Secara definitif pembiayaan korporasi adalah pelayanan yang diberikan kepada nasabah yang struktur keuangannya kuat (wholesale banking, corporate banking), serta diperuntukkan bagi nasabah corporate yang struktur keuangan perusahaannya dalam nominal yang besar, pada umumnya pembiayaan tersebut disalurkan dalam satuan milyar rupiah (Bank Syariah Mandiri, 2016, Kamus Bank Indonesia, 2013).

Ciri-ciri pembiayaan korporasi adalah pembiayaan dilakukan dalam satuan milyar, pembiayaan dilakukan oleh senior pembiayaan, pembiayaan diperuntukkan untuk satu proyek, dilakukan berdasarkan dengan prinsip syariah dan pihak nasabah harus berupa perusahaan (Davidson dan Gabriel, 1999).

Tujuan pembiayaan korporasi yaitu menyediakan dana bagi nasabah untuk meningkatkan tingkat produktifitasnya, menyediakan dana bagi nasabah apabila kekurangan untuk meningkatkan produksi usaha yang dilaksanakannya, dapat meningkatkan perkembangan usaha, dan meningkatkan tingkat likuiditas bank.

Produk-produk pembiayaan korporasi yaitu modal kerja dan investasi, dimana pada modal kerja terdapat empat pembiayaan yaitu pembiayaan musyarakah, dana 
berputar, mudharabah, dan resi gudang. Sedangkan pada pembiayaan investasi terdapat tiga pembiayaan yaitu murabahah, mudharabah, dan musyarakah (SPOB Pembiayaan Korporasi, 2012: 1).

\section{Pembiayaan Sindikasi (Syndicated Financing)}

Secara definitif pembiayaan sindikasi merupakan beberapa bank yang bergabung untuk menyalurkan pembiayaan skala besar. Terdapat tiga bentuk pembiayaan sindikasi, yaitu lead syndication, club deal dan sub syndication. Lead syndication merupakan sekelompok bank yang bersindikasi untuk membiayai usaha/proyek nasabah dan dipimpin oleh leader bank yang sudah ditunjuk oleh nasabah. Club deal merupakan kelompok sindikasi namun antar setiap bank tidak terdapat hubungan bisnis. Dan bentuk terakhir yaitu sub syndication merupakan sindikasi antar sesama bank peserta sindikasi, meskipun tidak terdapat hubungan dengan peserta sindikasi lainnya (Sumual, 2016: 105, Sholihin, 2010: 613).

Sedangkan menurut Stanley Hurn pembiayaan sindikasi syariah adalah dana yang disalurkan dalam bentuk pembiayaan oleh beberapa bank dengan persyaratan, kondisi dan menggunakan dokumen yang sama, serta diadministrasikan oleh agent yang sama (Azizah, 2009: 5, Firdaus, 2014).

Pada pembiayaan sindikasi terdapat dua tujuan pembiayaan yaitu untuk investasi dan modal kerja. Dimana setiap pembiayaan menggunakan akadnya masing-masing, akad pada pembiayaan investasi adalah akad murabahah, IMBT, dan MMQ. Sedangkan untuk modal kerja menggunakan akad musyarakah, mudharabah, kafalah dan wakalah (SPOB Pembiayaan Korporasi BSM,
2012: 1, Susana, Prasetyani, 2011: 470, Husaini, Suhadak, dan Zakiyah, 2014: 6).

Dalam melakukan sindikasi terdapat keuntungan bagi bank maupun nasabah. Keuntungan bagi bank yaitu mengelola BMPK, risk sharing dengan bank-bank lain, membangun hubungan kerjasama bank, meningkatkan FBI, reputasi dan menjadi learning process serta membuat bank dapat diakui dalam pasar sindikasi. Sedangkan keuntungan bagi nasabah yaitu dapat memperoleh pembiayaan dalam kuantitas yang kuat, mendapatkan kemudahan dalam bertransaksi karena hanya berhubungan dengan satu pihak yaitu arranger/agent, memupuk record sekaligus dengan beberapa bank, serta meningkatkan kredibilitas (Kuntadi, 2012: 6).

Manfaat sindikasi yaitu spreading risk (penyebaran risiko), convenience (kemudahan), sharing expertise (berbagi pengalaman), bank relationship (membina hubungan bank), meningkatkan FBI (pendapatan ujrah/fee) (SPOB Pembiayaan Korporasi BSM, 2012: 1).

Pihak-pihak sindikasi pada saat menjadi leader yaitu mudharib (nasabah), shahibul mal (investor), arranger (leader/ketua sindikasi), participant/lender (peserta sindikasi) yang didalamnya terdapat lead manager (kordinator) dan manager, selanjutnya terdapat agent bank (agencies/intermediary bank) yang didalamnya terdapat facility agent (agen fasilitas/penata usaha), security agent (agen penanggung jawab atas jaminan) dan escrow agent (agen yang memonitor rekening perantara/escrow account), selanjutnya underwriters (penjamin yang dilakukan dari pihak arranger) yang diantaranya terdapat fully underwriting dan partially underwriting, guarantor (penjamian yang dilakukan suatu badan usaha). Sedangkan sindikasi pada saat menjadi club deal 
yaitu lead bank (ketua sindikasi), agent bank (perantara bank), participant (peserta sindikasi), dan nasabah (SPOB Pembiayaan Korporasi BSM, 2012: 4-5).

Terdapat hak dan kewajiban dalam melakukan sindikasi, yaitu:

1. Hak dan Kewajiban Arranger

Negosiasi terms and conditions, Memperoleh data mengenai segala informasi nasabah baik data proyek maupun perkembangan hasil usaha, mengundang calon peserta dan mendapatkan fee, merancang dan mendistribusikan info memo, memberikan keterangan tentang pembiayaan sindikasi kepada calon peserta sindikasi, dan tidak memverifikasi data dari nasabah.

\section{Hak dan Kewajiban Bank Peserta}

Memperoleh data nasabah/proyek yang akan dibiayai, negosiasi mengenai seluruh syarat dan segala ketentuan melalui arranger, memperoleh fee/bagi hasil, hal lainnya sesuai dengan yang sudah diatur dalam akad perjanjian, melakukan analisa pembiayaan, memberikan surat persetujuan kepada arranger berdasarkan analisa dan keputusannya sendiri, mengirimkan dana pada jadwal pencairan setelah syarat pencairan dipenuhi nasabah, serta hal-hal lainnya sesuai isi akad pembiayaan.

3. Hak dan Kewajiban Agent

Mengatur agency fee, mengundurkan diri setiap saat, mengadministrasikan pembiayaan, intermediary party, serta hal lainnya sesuai perjanjian.

Jenis-jenis sindikasi yaitu lead syndication (sindikasi murni) dan club deal. Lead syndication merupakan pembiayaan yang disalurkan oleh beberapa bank yang tergabung dalam kelompok sindikasi berdasarkan kesepakatan yang telah disepakati. Sedangkan club deal dibentuk berdasarkan pembiayaan multilateral untuk menangani sebuah proyek nasabah yang berdasarkan dengan spesifik akad yang disepakati oleh semua pihak (SPOB Pembiayaan Korporasi BSM, 2012: 3-9).

Jenis-jenis akta dalam sindikasi yaitu akta akad pembiayaan sindikasi, akta pengikatan jaminan, akta perjanjian pembagian jaminan, akta perjanjian antar kreditur, dan akta perjanjian keagenan (Kuntadi, 2012: 34).

Risiko-risiko dalam melakukan sindikasi yaitu risiko pembiayaan (financing risk), risiko pasar (market risk), risiko likuiditas (liquidity risk), risiko hukum (legal risk), risiko reputasi (reputation risk), risiko operasional (operational risk), risiko imbal hasil (rate of return risk), risiko investasi (equity investment risk), risiko strategik (strategik risk), dan risiko kepatuhan (discipline risk) (Kebijakkan Pembiayaan Sindikasi BSM, 2012: 1-6).

\section{Peran Serta Bank Syariah Pada Pembiayaan Sindikasi}

Melalui kegiatan ekonomi produktif mengartikan bahwa bank syariah sudah mendukung transformasi dalam perekonomian, sehingga membuat bank syariah bernilai inklusif dimata masyarakat. Semakin berkembangnya pertumbuhan keuangan syariah maka pelayanan yang diberikan bank akan semakin meningkat lebih baik dari sebelumnya (Nisaputra, 2016).

Semakin meluasnya pembangunan perekonomian di Indonesia membuktikan bahwa peran LKB syariah semakin meningkat, hal tersebut mengharuskan bank syariah tampil terdepan agar berkesempatan untuk dapat bersindikasi dengan bank lainnya, meskipun bagi para stakeholders terdapat tantangan besar berupa inovasi produk keuangan demi meningkatkan minat masyarakat.

Setiap proyek nasabah yang diberikan pembiayaan secara sindikasi 
oleh bank-bank syariah ataupun bankbank konvensional, akan selalu diliput oleh beberapa media massa. Sehingga akan memasarkan hasil kinerja bank tersebut terhadap suatu proyek-proyek yang besar, serta menarik rasa percaya masyarakat dalam melakukan transaksi (Ifada, Husni, Liyantanto, 2011: 86).

\section{Mekanisme Pembiayaan Sindikasi Pada Bank Syariah}

Pemodal (investor) berperan aktif untuk mengelola keuangan dan manajerial dalam pembiayaan sindikasi. Karena, dasar pelaksanaan sindikasi merupakan partisipasi bisnis dalam melakukan peran/pekerjaannya. Meski demikian, bagi seorang mitra diperbolehkan untuk melaksanakan pekerjaannya lebih banyak dari pada mitra yang lainnya, sehingga bagi pihak tersebut diperbolehkan untuk menuntut bagian keuntungan tambahan bagi dirinya (Lewis dan Algauod, 2001: 63, Hidayat, 2011: 68, Iskandar, 2010: 49).

Terdapat dua bentuk sindikasi, yaitu pembentukkan pembiayaan lead syndication dan pembentukkan pembiayaan sindikasi club deal. Pembentukkan sindikasi tersebut berupa:

\section{BILATERAL}

\section{BANK}

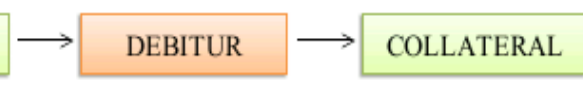

Gambar 4. Skema Sindikasi Bilateral Sumber: Maulidin, Overview Sindikasi BSM, 2017:3

1. Hubungan antara satu debitur dan satu kreditur.

2. Jaminan di ambil alih oleh kreditur.

3. Satu akad pembiayaan.

Sindikasi dengan skema bilateral yaitu perjanjian pembiayaan yang melibatkan dua pihak, yaitu nasabah dengan bank. Jaminan/agunan nasabah akan dikuasai oleh bank secara paripasu, serta pada pembiayaan tersebut akan menggunakan satu akad/kontral dimana menjadi simbol perjanjian yang sah antar keduanya (Kuntadi, 2012: 3).

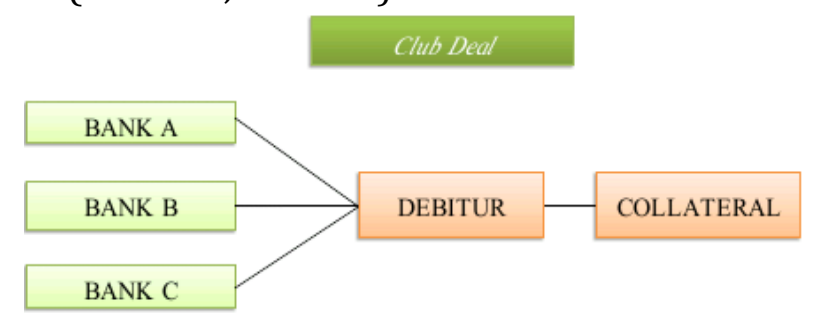

Gambar 5. Skema Sindikasi Club Deal

Sumber: Maulidin, Overview Sindikasi BSM, 2017:3

1. Pembentukkan fasilitas di arrange sendiri oleh debitur.

2. Fasilitas pembiayaan disalurkan oleh beberapa kreditur.

3. Jaminan akan dikuasai secara paripasu oleh bank.

4. Akad pembiayaan masing-masing. Sindikasi dengan skema club deal merupakan penyatuan modal tertentu yang dilakukan untuk mendanai sebuah proyek skala besar yang akan dijalankan oleh nasabah, namun antar bank tidak mempunyai ikatan ataupun hubungan bisnis. Dikarenakan pada skema club deal pembiayaan yang diperoleh tidak hanya bersumber dari bank syariah saja, melainkan dari bank konvensionalpun dapat turut serta dalam melaksanakan pembiayaan tersebut, sehingga untuk agunan atau jaminan akan dikuasai secara paripasu. Sedangkan pada kesepakatan antar bank tidak dibuatkan satu akad (kontrak). Melainkan pada akad pembiayaannya dibuat secara terpisah atau masing-masing berdasarkan dengan porsi yang akan diberikan, meskipun pada dasarnya isi dari setiap akad/kontrak tersebut sama (Kuntadi, 2012: 3). 


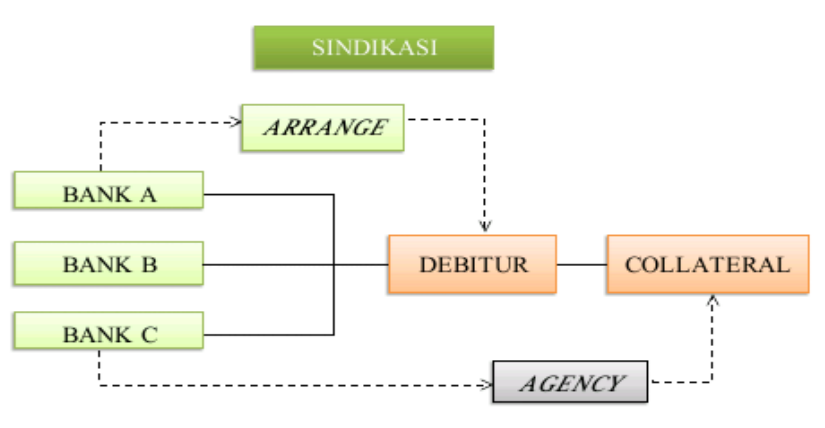

Gambar 6. Skema Sindikasi Sumber : Maulidin, Overview Sindikasi BSM, 2017: 4

1. Pembiayaan diberikan oleh beberapa kreditur dan difasilitasi oleh arranger yang sudah diberikan wewenang.

2. Jaminan dikuasai secara paripasu.

3. Satu akad pembiayaan.

4. Administrasi dan cheklist dokumen persyaratan pembiayaan, termasuk jaminan, difasilitasi oleh agency.

Sindikasi difasilitasi oleh arranger yang sudah diberikan mandat untuk mengatur seluruh proses pembiayaan, mulai dari pembiayaan diproses, serta memonitor setelah pembiayaan sindikasi selesai ditandatangani. Dilakukannya hal tersebut sebagai upaya bank dalam menerapkan prudential banking. Sedangkan untuk perjanjian menggunakan satu akad yang sama, dan untuk administrasi, cheklist dokumen persyaratan pembiayaan, termasuk jaminan serta memonitor escrow account akan ditangani oleh bagian agency yang merupakan perantara sekaligus sebagai penata usaha fasilitas sindikasi (Kuntadi, 2012: 3).

\section{Kerangka Pemikiran}

Pembiayaan sindikasi dilakukan untuk menyalurkan pembiayaan tanpa harus merasa khawatir akan melanggar ketentuan Batas Maksimum Pemberian Kredit. Dilakukannya pembiayaan sindikasi inipun demi meningkatkan pendapatan atau fee (Fee Based Income/FBI) bagi bank dengan meminimalisir adanya risiko pembiayaan besar yang terjadi, apabila terdapat risiko dikemudian hari maka seluruh anggota sindikasi harus bersedia menanggung secara bersamasama seluruh risiko yang muncul karena penyaluran pembiayaan tersebut. Berdasarkan penjelasan di atas, maka disusun poin-poin yang tergambar dalam kerangka pemikiran penelitian, seperti yang tertera pada gambar di bawah ini

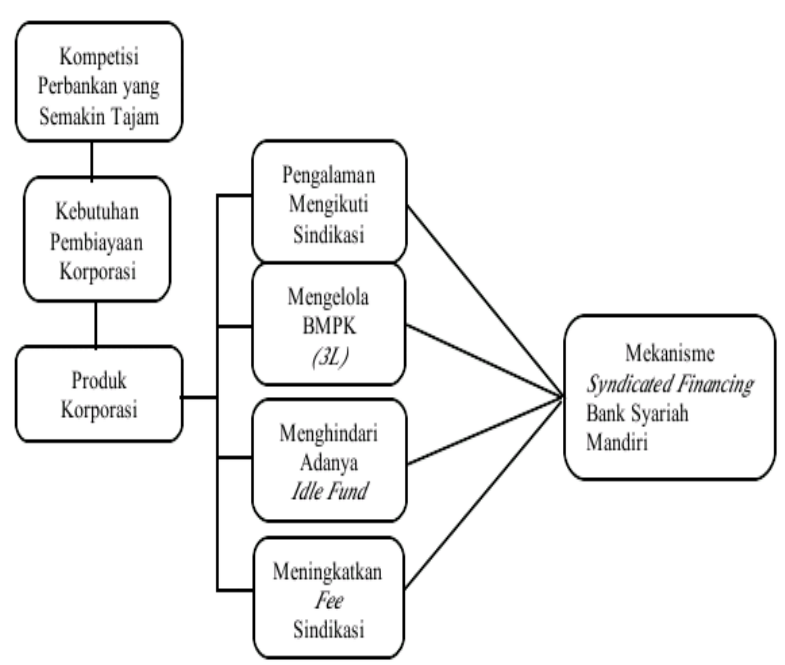

Gambar 7. Kerangka Pemikiran Sumber : Penulis, 2017

Kerangka pemikiran tersebut menjelaskan bahwa dengan berkembangnya sistem prekonomian pada saat ini, dapat meningkatkan kepentingan masyarakat akan perbankan syariah. Baik investasi ataupun modal kerja. Akibatnya kompetisi antar perbankan semakin tajam, sehingga antar perbankan harus bersaing secara sehat demi meningkatkan jumlah pendapatannya, serta mengharuskan perbankan untuk terjun kedalam sektor korporasi. Untuk itu perbankan harus menyiapkan produk-produk korporasi yang dapat memfasilitasi kebutuhan para nasabahnya (Ascarya, 2012: 203-204, Ghoniyah, 2012: 52, Pratama, Budiharto, Nand, 2016: 2, Muwardji, 2013: 99).

Dilakukannya pembiayaan korporasi tidak serta merta membuat 
bank syariah dapat memberikan pembiayaan secara bebas, dikarenakan setiap bank memiliki BMPKnya masingmasing. Hal itu menyebabkan pembiayaan sindikasi dilakukan dengan mendanai suatu proyek nasabah yang besar agar tidak melampaui BMPK. Dilakukannya sindikasi agar bank terlepas dari adanya idle fund, dan dana tersebut dapat dikelola serta menjadi lebih efektif bagi bank. Sindikasi pun dilakukan demi meningkatkan fee sindikasi, maka pendapatan bank pun akan lebih meningkat. Apabila terdapat risiko dari pembiayaan sindikasi maka para anggota sindikasi harus menanggungnya secara bersama-sama, sehingga akan meminimalisir adanya risiko-risiko kedepannya (Harmain, 2015: 102, Agustianto, 2016).

Pembiayaan sindikasi seharusnya dilakukan sejak dini, demi meningkatkan kerjasama antar bank serta dapat membantu untuk mempelajari mengenai sindikasi, dan menjadi sarana pembelajaran bagi setiap bank-bank junior untuk menyalurkan dananya melalui sektor korporasi. Maka dari itu mekanisme sindikasi yang berlaku, dapat menjadi contoh dalam melaksanakan sindikasi (Trihantana, 2015, Agustianto, 2016).

\section{Jenis Penelitian}

Jenis penelitian yaitu deskriptif kualitatif. Dengan menggunakan Model Miles and Huberman dengan pendekatan descriptive analysis. Objek penelitian ini difokuskan pada peran serta bank syariah serta mekanisme yang dilakukan BSM dalam melakukan sindikasi. (Sugiyono, 2010: 5-17, 427438).

\footnotetext{
Data primer pada penelitian adalah SPOB (Standar Prosedur Operasional Bisnis) Pembiayaan Korporasi, Surat Penawaran Sindikasi, Dokumen Perjanjian Antar Bank (PAB), Dokumen Analisa Pembiayaan Investasi, Analisa Manajemen Risko Pembiayaan,
}

Dokumen Kebijakan Pembiayaan, Syarat-syarat Sindikasi, Standar Prosedur Pembiayaan Sindikasi, Jenis Akad dalam Pembiayaan Sindikasi, Struktur Organisasi Khusus CBG I dan II. Sedangkan data sekunder diperoleh dari internet, undang-undang, buku, jurnal, skripsi, thesis dan literatur lainnya (Nazir, 2014: 39).

Teknik pengumpulan data yang dilakukan yaitu wawancara yang dilakukan kepada manajemen korporasi khususnya kepada bagian Corporate Banking Group (CBG) yang memahami tentang peran serta bank syariah serta mekanisme BSM dalam melakukan pembiayaan sindikasi, selanjutnya adalah observasi non partisipan yaitu pengamatan atas gejala, fenomena dan fakta empiris terkait masalah penelitian, serta tidak terlibat langsung melainkan hanya mengamati proses dari pembiayaan sindikasi BSM, serta dokumentasinya pada penelitian dan terakhir teknik kepustakaan yaitu referensi dari buku-buku, majalah, artikel dan sumber lainnya (Sugiyono, 2014: 231, Musfiqon, 2012: 120, Sugiyono, 2013: 326).

Teknik analisis data menggunakan data collection (mengumpulkan data) merupakan seluruh data terkait dengan penelitian dan dikumpulkan sesuai teknik pengumpulan data. Selanjutnya adalah data reduction (mereduksi data) yaitu memilih hal pokok serta penting. Selanjutnya adalah data display yaitu mendisplaykan data mengenai pembiayaan sindikasi berupa uraian pemaparan yang bersifat deskriptif. Tekhnik analisis terakhir yaitu data conclusions drawing/verifying (kesimpulan data) yaitu penarikan kesimpulan (Sugiyono, 2010: 427-438, Huberman dan Miles, 2014: 17, Sugiyono, 2013: 335). Dengan menggunakan alur penelitian yaitu: 


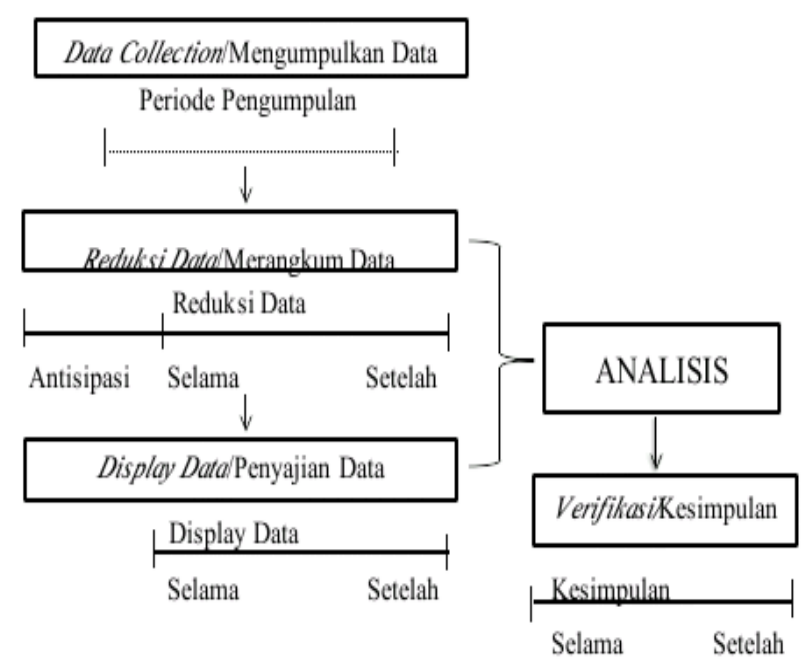

Gambar 8. Analisis Data Flow Model

Sumber : Sugiyono, 2013: 335, Miles dan Huberman, 2014: 18

Berdasarkan gambar diatas terlihat bahwa peneliti melakukan pengumpulan data, kemudian direduksi dan dilanjutkan dengan bentuk penyajian data dapat berupa tabel, grafik atau yang lainnya guna mempermudah analisis dalam menarik kesimpulan. Selanjutnya skema yang menggambarkan peneliti melakukaan analisis data dengan model interaktif sebagai berikut (Sugiyono, 2013: 335).

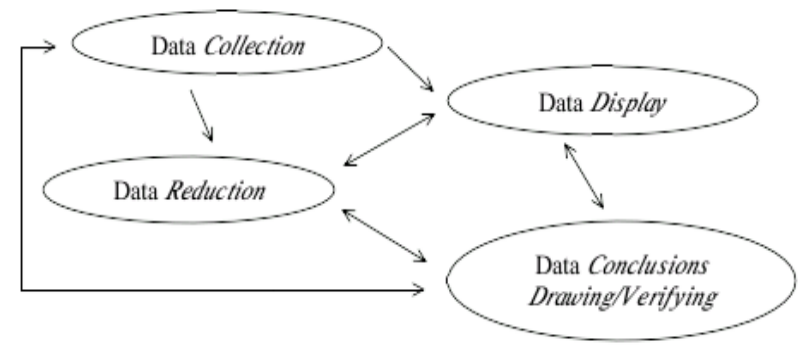

Gambar 9. Analisis Data Interactive Model

Sumber: Sugiyono, 2013: 335, Miles dan Huberman, 2014: 20

Berlandaskan hal diatas dapat penulis gambarkan alur penelitian untuk menjelaskan mengenai tahapantahapan dari setiap prosedur yang dilakukan peneliti, sehingga dapat disimpulkan bagaimana peran serta bank syariah dalam melaksanakan sindikasi dan bagaimana mekanisme yang diterapkan dalam menganalisa sampai dengan proses

penandatanganan kontrak dan memonitor berjalannya proyek nasabah. Berikut tergambar alur penelitian yang dilakukan, yaitu:

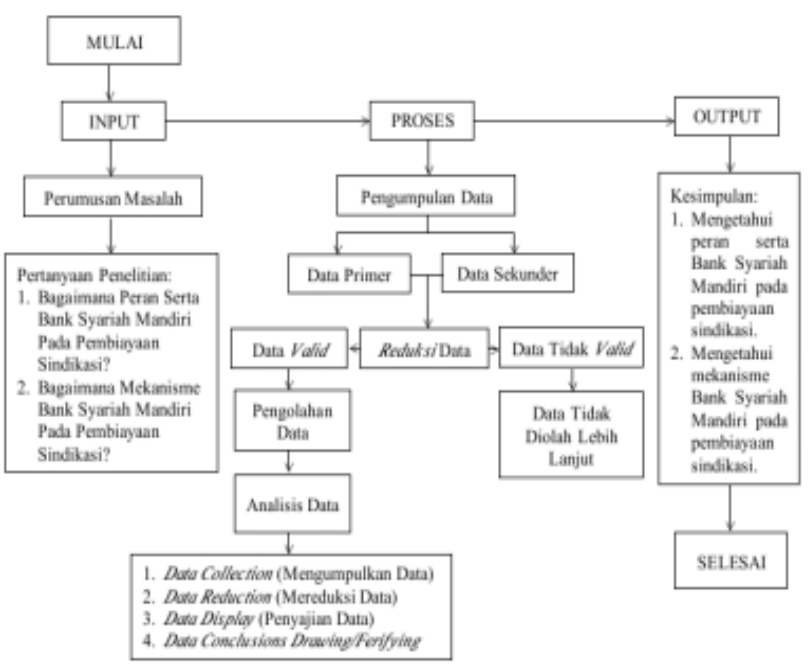

Gambar 10. Diagram Alur Penelitian Sumber: Penulis, 2017

\section{HASIL DAN PEMBAHASAN}

\section{Peran Serta Bank Syariah Mandiri dalam Pembiayaan Sindikasi}

Pembiayaan korporasi pada BSM sudah diterapkan sejak tahun 2001 dengan terbentuknya bagian khusus yang menangani korporasi dan sindikasi yaitu Corporate Banking Group (CBG), siring berkembangnya sektor korporasi dikalangan perbankan, maka pada tahun 2005 BSM melaunching desk sindikasi demi mengembangkan potensi sindikasi syariah. Hal tersebut didasari dengan bentuk dukungan BSM dalam membantu ekspansi bisnis nasabah korporasi melalui penyaluran pembiayaan dengan pertumbuhan positif nya bank. Melalui sindikasi maka mempengaruhi tingkat pertumbuhan jumlah pembiayaan BSM (Maulidin, Divisi $C B G, 2017)$, hal tersebut terlihat pada diagram dibawah ini: 


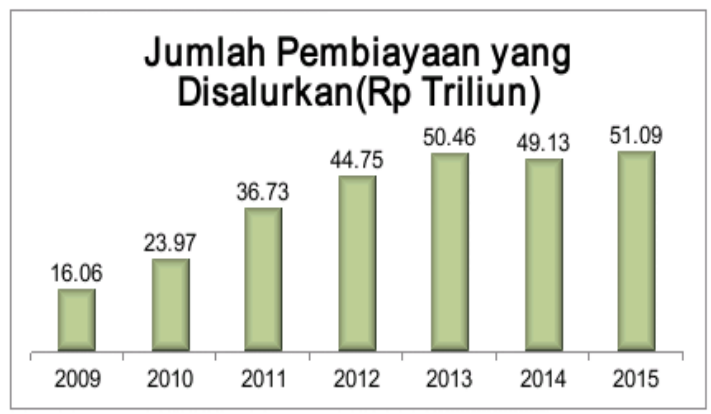

Gambar 11.

Perkembangan Jumlah Pembiayaan

Sumber: Annual Report BSM, 2009-2015

Dari data diatas dapat dijelaskan bahwa penyaluran pembiayaan BSM dari setiap tahunnya semakin meningkat, dimulai sejak tahun 2009 sampai tahun 2015. Meskipun pada tahun 2014 terdapat penurunan pembiayaan sebesar Rp. 1,33 T dari tahun 2013 yang tingkat pembiayaannya mencapai sebesar Rp. 50,46 T. Sedangkan pada tahun 2015 penyaluran pembiayaan BSM mengalami peningkatan Rp. 1,96 T dari tahun sebelumnya.

Meningkatnya jumlah pembiayaan mempengaruhi meningkatnya kinerja pembiayaan unit bisnis Wholesale Banking yaitu pada tahun 2015 mencapai sebesar Rp. 23,81 T, dibandingkan kinerja Wholesale Banking tahun 2014 yaitu sebesar Rp. 21,73 T. Pembiayaan Wholsale Banking mengalami peningkatan Rp. 2,09 T atau 9,61\% dari tahun sebelumnya. Dimana peningkatan tersebut didapatkan dari bagian Corporate Banking dan Commercial Banking berdasarkan dari hasil penyaluran pembiayaan (Annual Report BSM, 2015: 4).

Pada tahun 2014 BSM menyalurkan pembiayaan korporasi Rp. 16,19 T yang berarti tumbuh sebanyak 30,33\% dari tahun 2013 yaitu Rp. 12,42 T. Pembiayaan korporasi diarahkan sebagai bentuk perluasan dan penyatuan bisnis. Sementara itu pembiayaan korporasi difokuskan kepada tiga sektor besar saja, antara lain yaitu sektor jasa dunia usaha, sektor perdagangan dan konstruksi (Maulidin, Divisi CBG, 2017).

Sedangkan pembiayaan sindikasi tahun 2014 BSM berhasil menyalurkan pembiayaannya Rp. 2,77 T. Selama tahun 2014 pembiayaan sindikasi berhasil disalurkan baik itu sindikasi murni, club deal, dan bilateral (sebagai underwriter) yang berarti tumbuh $\mathrm{Rp}$. $1,14 \mathrm{~T}$ atau $110,82 \%$ dari data sebelumnya yaitu pada tahun $2013 \mathrm{Rp}$. 1,6 T dengan pendapatan FBI Rp. $42 \mathrm{M}$ (Maulidin, Divisi CBG, 2017).

Diperoleh tiga sektor industri terbesar pada portofolio sindikasi di BSM yaitu perdagangan besar Rp. $554 \mathrm{M}$ atau 20\%, agribisnis Rp. 487,5 M atau 18\%, dan transportasi laut Rp. 481,3 M atau $17 \%$. Terdapat beberapa sektor yang BSM salurkan melalui sindikasi, yaitu (Maulidin, Divisi $C B G, 2017$ ):

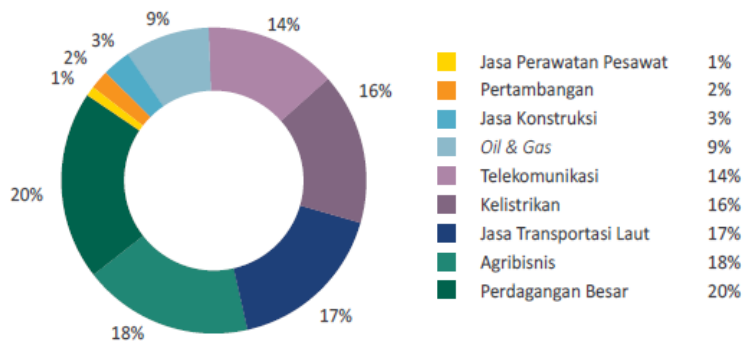

Gambar 12. Sektor Pembiayaan Sindikasi

Sumber: Maulidin, Divisi $C B G, 2017$

Keterangan di atas merupakan sektor-sektor yang sudah dibiayai oleh BSM, dengan pembiayaan terbesar yaitu kepada sektor perdagangan besar sebanyak $20 \%$, sedangkan sektor paling kecil adalah jasa perawatan pesawat dengan jumlah sebanyak 1\%. Dari beberapa sektor tersebut BSM berperan sebagai arranger yang mengatur segala kebutuhan pembiayaan serta memonitor usaha nasabah setelah kontrak pembiayaan ditandatangani (Maulidin, Divisi CBG, 2017).

Selain itu BSM berperan sebagai anggota dalam keikutsertaannya 
dipimpin oleh leader dari anggota sindikasi. Dari beberapa pengalaman BSM dalam bersindikasi, berdasarkan proyek-proyek diatas BSM lebih banyak berperan sebagai leader dibandingkan sebagai anggota, mengingat kemampuan BSM yang berpotensi besar untuk ikut terlibat dalam membiayai sektor korporasi. Dikarenakan progres BSM yang memiliki pangsa dibidang retail dan korporasi, meskipun sektor korporasi dilakukan BSM sebagai alternatif bank dalam menyalurkan pembiayaan dan dapat mensharing risiko (Maulidin, Divisi $C B G, 2017$ ).

Bergeraknya BSM kedalam sektor korporasi hanya 25\% dari jumlah DPK, sedangkan $75 \%$ tetap bergerak dibidang retail. Berkembangnya BSM dibidang korporasi bukan berarti meninggalkan tujuan utamanya. Dimana BSM tetap melaksanakan kewajibannya dengan mengutamakan penyaluran kepada sektor retail, sebagai pelengkap BSM tetap menyalurkan pembiayaannya kepada sektor korporasi (Maulidin, Divisi $C B G$, 2017).

Terlebih BSM sudah cukup dikenal dikalangan pasar korporasi, dalam menyebarkan pembiayaan dengan skala yang besar melalui cara bersindikasi. Ditambah dengan jenis-jenis produk BSM yang lebih bersaing di pasar dengan harga $10 \%$ sampai $11 \%$, karena didalam pembiayaan sindikasi pihak bank dapat memaintenance produknya dan dengan proses analisa yang mendalam membuat sindikasi dapat disalurkan dengan aman meskipun jumlahnya sangat besar (Maulidin, Divisi $C B G$, 2017).

Peran serta BSM dalam mengikuti sindikasi bukan sekedar demi meningkatkan asset perbankan syariah saja, melainkan untuk menjaga likuiditas bank. Bentuk kontribusi BSM melalui sindikasi merupakan usaha dalam meningkatkan tingkat pembangunan nasional. Sehingga membuat banyak bank ikut berkontribusi dalam pembangunan nasional semakin meningkat, sehingga banyak bank syariah mulai bergerak kedalam sektor korporasi secara lebih agresif ditambah dengan keikutsertaan BPD dalam mengikuti sindikasi (Maulidin, Divisi CBG, 2017).

Peranan BSM dapat dikatakan baik dikalangan pasar korporasi, dikarenakan sejak BSM melaksanakan sindikasi sebagai anggota, BSM sudah dapat memberikan pembiayaan sindikasi dua kali/lebih dalam satu tahun, track record BSM dalam menjadi anggota sindikasi sudah sebanyak sepuluh kali dengan membiayai beberapa proyek-proyek besar (Maulidin, Divisi CBG, 2017) diantaranya:

Tabel 1. Proyek Sindikasi BSM

(Anggota)

\begin{tabular}{|clc|}
\hline \multicolumn{3}{|c|}{ Proyek-Proyek Sindikasi } \\
\hline$N_{0}$ & \multicolumn{1}{c|}{ Jenis Proyek } & Posisi \\
\hline 1 & Proyek Pembangkit Listrik Tenaga Mini Hidro (PLTMH) & Anggota \\
\hline 2 & Proyek Pembangunan Kota Casablanka 2 & Anggota \\
\hline 3 & Proyek Modal Kerja Pembelian BBM & Anggota \\
\hline 4 & Proyek Perkebunan Kelapa Sawit & Anggota \\
\hline 5 & Proyek Investasi Kapal Tangker & Anggota \\
\hline 6 & Proyek Pupuk Kaltim & Anggota \\
\hline 7 & Proyek Pelabuhan Indonesia & Anggota \\
\hline
\end{tabular}

Sumber: Maulidin, Divisi CBG, 2017

Tabel diatas menjelaskan bahwa BSM sudah membiayai proyek besar dengan posisinya sebagai anggota sindikasi, data tersebut merupakan proyek-proyek yang terdaftar pada saat ini, diluar beberapa proyek yang sudah selesai. Melalui sektor korporasi membuat BSM lebih dikenal dimata masyarakat dan perusahaanperusahaan besar karena dapat mengoptimalkan sektor korporasi tanpa mengesampingkan sektor retailnya yang merupakan tujuan utama adanya bank syariah (Maulidin, Divisi CBG, 2017).

Semakin berkembangnya BSM disektor korporasi membuat posisi BSM lebih dipercaya untuk menangani 
proyek-proyek nasabah. Dimana pada pembiayaan sindikasi BSM lebih dipercaya sebagai leader sindikasi, jumlah proyek yang berhasil ditangani oleh BSM dengan posisinya sebagai leader sudah sebanyak dua puluh sampai dua puluh lima kali, adapun proyek-proyek yang BSM tangani, diluar dari proyek yang sudah berakhir pembiayaannya (Maulidin, Divisi $C B G$, 2017) yaitu:

Tabel 2. Proyek Sindikasi BSM (Leader)

\begin{tabular}{|llc|}
\hline \multicolumn{3}{|c|}{ Proyek-Proyek Sindikasi } \\
\hline $\mathrm{N}_{0}$ & \multicolumn{1}{|c|}{ Jenis Proyek } & Posisi \\
\hline 1 & Proyek Telekomunikasi & Leader \\
\hline 2 & Proyek Investasi Kapal Tangker & Leader \\
\hline 3 & Proyek Oil and Gas & Leader \\
\hline 4 & Proyek Investasi Jenset & Leader \\
\hline 5 & Proyek Pembangkit Listrik Tenaga Disel (PLTD) & Leader \\
\hline 6 & Proyek Energi Prima & Leader \\
\hline 7 & Proyek Pembangkit Listrik Tenaga Mini Hidro(PLTMH) & Leader \\
\hline 8 & Proyek Pembiayaan Trader Oil & Leader \\
\hline 9 & Proyek Pembiayaan LPG Plan & Leader \\
\hline
\end{tabular}

Sumber: Maulidin, Divisi CBG, 2017

Proyek-proyek yang BSM tangani merupakan jenis proyek dalam skala nasional dan lebih strategis dengan nilai pembiayaan yang besar, dimana jenisjenis sindikasi pada BSM, yaitu: Sindikasi murni yang merupakan perjanjian sindikasi antara BSM dengan sesama bank syariah. Selanjutnya adalah sindikasi club deal yang merupakan perjanjian antara BSM beserta bank syariah ataupun dengan bank konvensional. Dikarenakan dengan menggunakan skema club deal antar sesama bank dapat memiliki ketentuan masing-masing dengan bagian yang akan dibiayainya berdasarkan kesepakatan antara seluruh pihak, tetapi apabila terdapat keuntungan maka bank yang terlibat akan memperoleh keuntungan sesuai bagian yang dibiayainya (Maulidin, Divisi $C B G$, 2017).

\section{Mekanisme Pembiayaan Sindikasi pada Bank Syariah Mandiri}

Skema sindikasi di BSM pada prosesnya dibutuhkan waktu paling sedikit yaitu enam bulan, dikarenakan nasabah pembiayaan sindikasi harus melengkapi seluruh persyaratan dari bank untuk melakukan proses analisa pembiayaan (Maulidin, Divisi $C B G$, 2017).

Syarat-syarat tersebut berupa bukti permohonan dari nasabah, buktibukti legalitas pemohon, bukti-bukti legalitas usaha, dokumen pendukung berupa jenis kontrak, company profile, dan lain-lainnya. Selanjutnya laporan keuangan dua tahun terakhir dan laporan keuangan tahun berjalan, serta bukti kepemilikkan agunan (Maulidin, Divisi $C B G$, 2017).

Daftar tersebut merupakan ketentuan-ketentuan yang harus nasabah lengkapi apabila ingin mengajukan pembiayaan korporasi, jika terdapat berkas yang belum dilampirkan maka prosesnya tidak dapat dilanjutkan. Hal tersebut dilakukan karena BSM harus menerapkan standar prudential banking untuk menghindari apabila terjadi risiko bagi bank.

Dengan terpenuhinya seluruh persyaratan bank, maka proses analisa pembiayaan sindikasi dapat segera dilaksanakan, agar pembiayaan nasabah dapat segera direalisasikan. Terdapat dua tingkatan dalam proses untuk mendapatkan pembiayaan sindikasi, yaitu primary market syndication yang merupakan pasar dimana berlangsungnya proses sindikasi mulai dari pembentukkan sampai sebelum ditandatanganinya akad pembiayaan sindikasi. Maka dari itu seluruh bank peserta ikut menandatangani akad tersebut, selanjutnya bank tersebut disebut peserta langsung. Sedangkan tingkatan yang kedua yaitu secondary market syndication merupakan pasar 
yang terbentuk apabila salah satu peserta langsung sindikasi menjual sebagian/seluruh partisipasinya kepada bank/lembaga keuangan lainnya, kemudian bank tersebut menjadi peserta sindikasi baru. Terjadinya penjualan dan pembelian partisipasi pada pasar dilakukan apabila pembiayaan sindikasi berbentuk "Transferable Financing Facility (TFF)" atau bisa diistilahkan sebagai selling down (Maulidin, Divisi CBG, 2017). Tahap-tahap pembentukkan sindikasi yaitu:

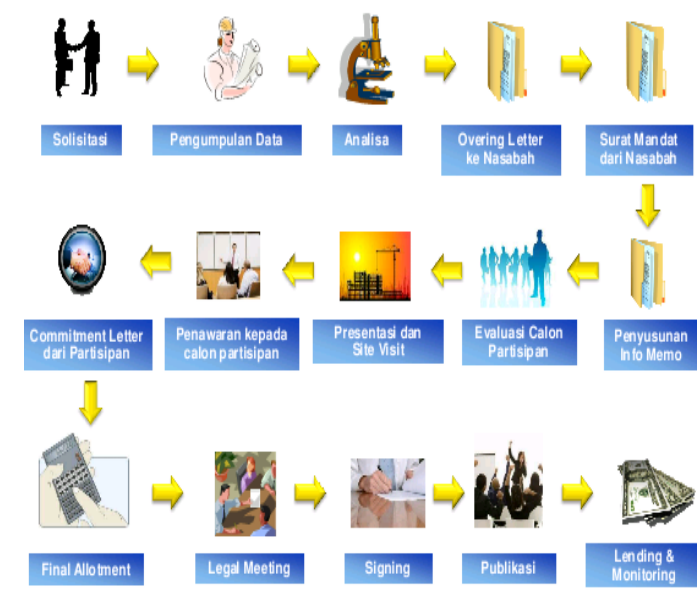

Gambar 13.

Skema Pembiayaan Sindikasi BSM

Sumber: Yessi, Divisi Corporate Banking Group, 2017

Mekanisme proses pembentukkan pembiayaan sindikasi oleh BSM sebagai Lead Bank diatas sebagai berikut:

1. Bank beserta nasabah melakukan negosiasi, didalam negosiasi itu bank menawarkan produk apa yang cocok serta jumlah angsuran yang harus nasabah bayarkan sekaligus dengan jumlah margin yang ditawarkan BSM, apabila nasabah setuju maka nasabah akan sekaligus meminta BSM untuk mengatur pembentukkan sindikasi tersebut.

2. Selanjutnya yaitu mengumpulkan data berupa pelengkapan persyaratan dari bank seperti bukti permohonan, bukti legalitas pemohon, bukti legalitas usaha, dokumen-dokumen pendukung, financial statement serta bukti-bukti kepemilikkan agunan nasabah.

3. BSM membuat analisis dari seluruh berkas-berkas terkait apakah nasabah tersebut layak diberikan pembiayaan, apabila seluruh proses analisis sudah sesuai maka BSM akan mengirimkan overing letter.

4. BSM akan mengirimkan offering letter dengan kondisi underwitten basis yaitu dimana BSM melakukan pengikatan diri untuk menyediakan sebagian (partially underwritten) atau seluruh (fully underwritten) dari seluruh jumlah dana pembiayaan. Partially Underwriten merupakan underwritter yang hanya mengikatkan diri dan bertanggung jawab atas sebagian tertentu dari permohonan nasabah, sedangkan sisanya ditawarkan kepada bank lainnya melalui sindikasi. Apabila tidak ada bank lain yang berminat, maka masabah hanya memperoleh pembiayaan sebesar yang dijanjikan oleh underwritter (penjamin).

5. Selanjutnya adalah fully underwritten merupakan underwritter yang sudah menyediakan seluruh pembiayaan yang dimohon oleh nasabah. Jika belum terdapat bank yang bersedia, maka underwritter sendiri yang menyediakan seluruh pembiayaan yang dimohon nasabah. Atau dapat pula on best effort basis dimana BSM tidak memberikan komitmen kepada calon nasabah bahwa dana yang dibutuhkannya dapat diperoleh, tetapi berjanji untuk mencapai jumlah yang disepakati. Apabila arrangers tidak berhasil mengumpulkan sejumlah partisipan, terdapat kemungkinan bahwa calon nasabah akan memperoleh pembiayaan dengan nominal yang lebih kecil. 
6. Setelah offering letter dikirimkan, selanjutnya BSM akan meminta mandat dan penunjukkan sebagai MLA kepada nasabah untuk mengatur pembentukkan sindikasi guna membiayai kebutuhan usaha nasabah. Dengan mandat tersebut maka BSM dapat memberikan data atau informasi tentang nasabah.

7. Setelah menerima mandate dari nasabah, BSM akan segera menyusun information memorandum (info memo) yang berisikan informasi mengenai profil usaha nasabah, dan term \& condition dari pembiayaan sindikasi. Seluruh sumber data dari info memo sepenuhnya berasal dari nasabah.

8. Setelah itu BSM akan menawarkan atau memasarkan pembiayaan proyek tersebut kepada beberapa bank yang mempunyai kemampuan sindikasi dengan mengirimkan surat penawaran disertai info memo. BSM dapat pula mengadakan penawaran terbuka (public offering) dengan mengundang bank dimana nasabah dan MLA akan melakukan presentasi mengenai proyek yang dibiayai.

9. Setelah menerima jawaban dari surat penawaran dan info memo, MLA beserta lembaga keuangan calon anggota sindikasi melakukan analisis terhadap proyek tersebut dan mempresentasikan kepada para komite pembiayaan dari masingmasing bank.

10. Apabila lembaga keuangan calon anggota sindikasi memiliki ketertarikan pada usaha nasabah, maka setiap bank akan menyampaikan komitmen mereka kedalam bentuk participation letter.

11. Setelah para partisipan menyatakan kesediaan untuk ikut berpartisipasi, maka BSM bersama peserta sindikasi akan memberikan term sheet final kepada nasabah meliputi mencantumkan jumlah limit pembiayaan dan porsi partisipasi dari setiap peserta sindikasi.

12. Selanjutnya BSM wakil dari lembaga keuangan peserta sindikasi, konsultan hukum independen atau lawyer, notaris dan nasabah mengadakan pertemuan (legal meeting) untuk membahas draft akad berikut kelengkapannya, pembagian jumlah partisipasi (reallotment) apabila terjadi kelebihan permintaan terhadap total fasilitas yang ditawarkan, persyaratan pembiayaan, serta penunjukan facility agent dan security agent, sekaligus mempersiapkan segala sesuatu untuk penandatanganan akad, termasuk perjanjian antar bank dan perjanjian mengenai pembagian jaminan yang akan diperoleh oleh setiap bank.

13. Selanjutnya jaminan akan dikuasai secara paripasu. Contohnya seperti: Apabila PT. A memiliki pembiayaan sindikasi pada Bank X, Bank Y, dan Bank $\mathrm{Z}$ dengan menjaminkan suatu bangunan pabrik beserta isinya diatas tanah HGB dengan nilai jaminan Rp. 600 Milyar. Maka jaminan untuk pembiayaan yang diperoleh setiap bank sebagai berikut:

Bank X RP. 300 Milyar

Bank Y Rp. 100 Milyar

Bank Z Rp. 50 Milyar

Jumlah Rp. 450 Milyar

Maka jaminan yang diperoleh oleh masing-masing bank adalah:

Bank X (300/450) x $600=400$ Milyar

Bank Y (100/450) x $600=133$ Milyar

Bank Z (50/450) X $600=67$ Milyar

14. Setelah sindikasi terbentuk maka dilakukan penandatanganan akad 
beserta perjanjian yang mengikutinya.

15. Mengingat pada umumnya proyek tersebut berskala besar, maka acara penandatanganan akad tersebut biasanya diikuti dengan pemasangan iklan (public expose) diharian terkemuka tentang pembiayaan sindikasi yang dilakukan.

16. Setelah seluruh proses pembentukkan sindikasi selesai maka tugas BSM sebagai lead sindikasi adalah mencairkan pembiayaan tersebut dan memonitor berjalannya proyek.

17. Dengan terbentuknya facility agent sebagai agent untuk menatausahakan, mengoperasikan, mengelola serta mengadministrasikan setelah financing agreement ditandatangani. pencairan pembiayaan maupun perhitungan margin pembiayaan. Selanjutnya adalah security agent sebagai penanggung jawab serta membantu dan menyimpan, mengadministrasikan serta updating dokumen jaminan, dan pemantauan appraisal report pada pembiayaan sindikasi. Serta escrow agent sebagai agent dalam membentuk, menatakerjakan serta memonitor escrow account pembiayaan sindikasi. Keberadaan escrow agent ini diperlukan apabila terjadi permasalahan terhadap persyaratan, yang mengharuskan adanya persetujuan bank saat terjadinya pemasukkan dan pengeluaran.

18. Tugas lead arranger dalam memonitor berjalannya proyek nasabah yaitu dengan memastikan bahwa setiap tahapan proses pembiayaan telah dilakukan sesuai ketentuan yang berlaku, lalu memonitor adanya pemenuhan persyaratan yang didalamnya termasuk monitoring proses penguasaan jaminan, penutupan asuransi, selanjutnya adalah monitoring limit pembiayaan, monitoring portofolio pembiayaan, monitoring kegiatan usaha nasabah. On site monitoring merupakan pemantauan langsung yang dilakukan melalui kunjungan/langsung kelapangan oleh unit bisnis secara insidentil bilamana terdapat unfavorable information. Sedangkan on desk monitoring merupakan proses pemantauan secara administratif, seperti halnya laporan-laporan, laporan keuangan, kelengkapan dokumen, informasi dari pihak ketiga, plafond dan saldo outstanding fasilitas pembiayaan serta mutasinya.

19. Selanjutnya adalah monitoring kewajaran pembiayaan, monitoring pembayaran, monitoring kewajiban jatuh tempo, monitoring masa berlaku asuransi, monitoring masa berlaku legalitas usaha, monitoring masa berlaku pembiayaan, monitoring pembentukkan Penyisihan Penghapusana Aktiva (PPA) dan monitoring penyampaian laporan nasabah kepada lead arranger.

20. Dalam mencairkan pembiayaan sindikasi, bank tidak serta merta langsung mencairkan pembiayaan tersebut secara utuh, melainkan dengan cara diangsur setiap kali nasabah membutuhkannya. Dilakukannya hal itu sebagai bentuk monitoring dalam memantau perkembangan proyek nasabah. Untuk itu alur penarikkan pinjaman yaitu: 


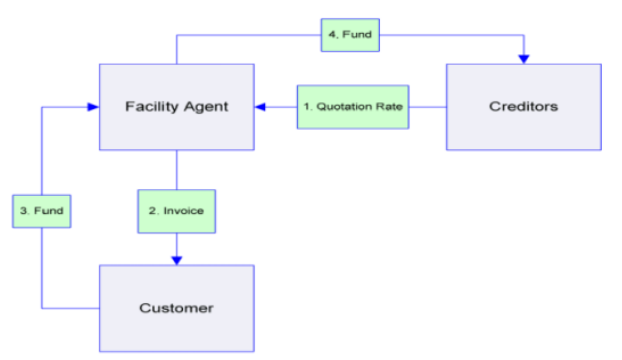

Gambar 14.

Alur Penarikan Pinjaman

Sumber: Yessi, Overview Sindikasi, 2017: 25

a. Nasabah akan memberikan pemberitahuan penarikan pembiayaan (notice of drawdown) kepada facility agent.

b. Selanjutnya facility agent akan mengirimkan pemberitahuan penarikan (notice of drawdown) kepada leader sindikasi.

c. Setelah itu lead sindikasi akan memberikan dana nya kepada facility agent.

d. Facility agent akan memberikan dananya kepada nasabah.

21. Selama berjalannya proyek nasabah, facility agent bertugas dalam pengumpulan margin, yang selanjutnya facility agent akan menyerahkan margin tersebut kepada lead sindikasi. Alur pembayaran margin yaitu:

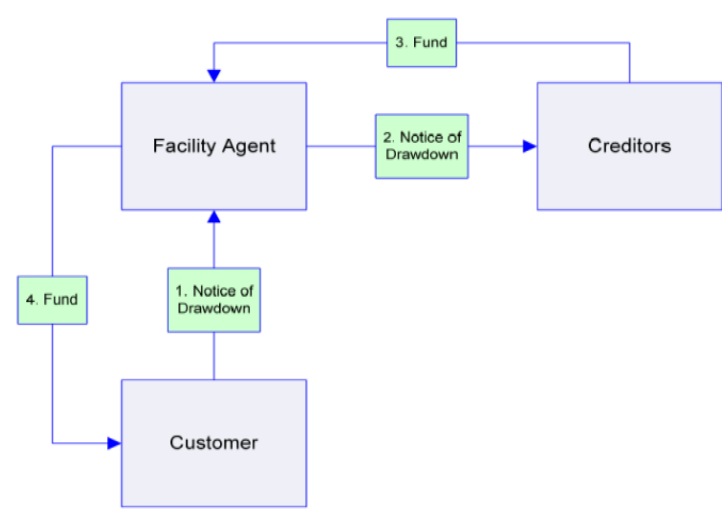

Gambar 15.

Alur Pembayaran Margin

Sumber: Yessi, Overview Sindikasi, 2017: 26

a. Bank/Lead Sindikasi mengirimkan surat penawaran suku bunga kepada facility agent untuk diberikan kepada nasabah. b. Selanjutnya facility agent akan mengirimkan invoice (faktur) kepada nasabah sebagai dokumen pernyataan tagihan.

c. Setelah itu nasabah akan memberikan dananya kepada facility agent.

d. Terakhir facility agent akan memberikan dananya kepada lead sindikasi.

22. Terakhir adalah setelah seluruh proses sindikasi selesai dan nasabah ingin membayar (melunasi) pinjamannya kepada lead sindikasi, maka facility agent akan memberikan invoice sebagai pemberitahuan atas tagihan nasabah. Mekanisme pembayaran pokok pinjaman yaitu:

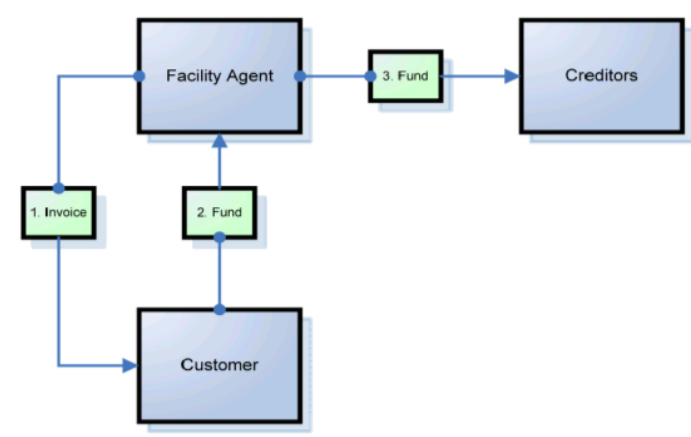

Gambar 16.

Alur Pembayaran Pokok Pinjaman Sumber: Yessi, Overview Sindikasi, 2017: 27

a. Facility agent memberikan invoice (faktur) kepada nasabah sebagai dokumen pernyataan tagihan.

b. Setelah itu nasabah akan memberikan dananya kepada facility agent.

c. Terakhir facility agent akan memberikan dananya kepada lead sindikasi.

23. Setelah nasabah menyelesaikan segala hutang piutangnya, maka seluruh perjanjian sudah selesai. Hal itu karena nasabah sudah menyelesaikan seluruh kewajibannya untuk menyelesaikan pinjamannya. Begitupun bagi bank sudah menyelesaikan tanggung 
jawabnya sebagai leader sindikasi kepada para partisipan maupun nasabah.

Selanjutnya apabila BSM sebagai participant atau anggota sindikasi, yaitu:

1. BSM menerima surat penawaran sindikasi dari MLA atau lead bank sindikasi.

2. Selanjutnya melakukan analisis pembiayaan atas kelayakan proyek, yaitu memperhatikan prinsipprinsip syariah, ketentuan perundang-perundangan yang berlaku, PBI yang terkait, dan ketentuan internal bank. Selanjutnya menggambarkan seluruh informasi terkait usaha termasuk hasil BI checking dan menggambarkan kelayakan usaha. selanjutnya menilai pembiayaan secara obyektif dengan menganalisis pembiayaan secara benar, bukan hanya formalitas semata, menganalisis minimal aspek 5C yaitu karakter, kemampuan, agunan, prospek usaha nasabah, modal, aspek lingkungan, dan sumber pelunasan pembiayaan.

3. Memastikan bonafiditas bank yang akan bertindak sebagai lead bank apabila BSM akan berpartisipasi dalam pembiayaan sindikasi, selanjutnya senantiasa mempertimbangkan seluruh faktor risk \& return balance dalam pemutusan pembiayaan. Setiap nota analisa pembiayaan harus memuat rekomendasi yang jelas (prinsip dual control).

4. Selanjutnya pejabat pemberian pembiayaan dapat melakukan penolakan apabila segala persyaratan yang sudah ditentukan tidak dapat dipenuhi oleh bank.

5. Setelah dianalisa terkait analisis pembiayaan sindikasi, selanjutnya adalah penerbitan surat persetujuan oleh komite pembiayaan yang berwenang.
6. Mengirimkan surat keikutsertaan pembiayaan kepada lead sindikasi.

7. Berkontribusi dalam legal meeting yang diselanggarakan oleh MLA sindikasi untuk membahas draft akad beserta kelengkapannya.

8. Dan terakhir adalah ikut serta untuk menandatangani akad pembiayaan sindikasi.

\section{Penanganan Pembiayaan Bermasalah yang di Tempuh oleh Bank Syariah Mandiri}

1. Penyelamatan Pembiayaan

Bermasalah

Dalam menangani adanya pembiayaan macet yang masih memiliki potensi usaha, kinerja, kemampuan membayar serta itikad baik, dengan tujuan meminimalkan risiko. Dengan cara:

a. Restrukturisasi Pembiayaan

BSM melakukan upaya untuk membantu menyelesaikan kewajiban nasabah, diselesaikannya hal tersebut melalui cara rescheduling (penjadwalan kembali) yaitu melakukan perubahan atas jadwal/jangka waktu kewajiban pembiayaan yang harus dibayarkan nasabah, selanjutnya reconditioning (persyaratan kembali) yaitu perubahan atas seluruh atau sebagian syarat-syarat pembiayaan, tanpa harus menambahkan sisa pokok angsuran yang harus dibayarkan nasabah kepada pihak bank yang didalamnya meliputi tentang perubahan jadwal pembayaran, jumlah angsuran, jangka waktu, nisbah, proyeksi nisbah dan pemberian potongan, serta restructuring (penataan kembali) yaitu perubahan atas persyaratan pembiayaan meliputi penambahan dana pembiayaan, konversi akad pembiayaan, konversi pembiayaan menjadi surat berharga syariah berjangka waktu 
menengah dan konversi pembiayaan menjadi penyertaan modal sementara pada perusahaan nasabah.

b. Management Assistancy

Upaya BSM dengan memberikan bantuan konsultasi dan manajemen profesional yang memiliki potensi usaha untuk menyelesaikan kewajibannya, tetapi lemah dalam pengelolaan perusahaan (nasabah mengalami kesulitan management).

2. Penyelesaian

Pembiayaan

Bermasalah

Tindakan-tindakan yang dilakukan BSM untuk mengatasi pembiayaan bermasalah dapat diselesaikan seluruhnya ataupun sebagiannya dengan cara:

a. Novasi

Suatu akad yang menyebabkan terhapusnya perikatan, dimana pada saat yang sama timbulah perikatan yang lain sebagai pengganti dari perikatan sebelumnya. Terdapat dua cara dalam melakukan novasi, yaitu:

1) Novasi Obyektif

Merupakan obyek akad yang diganti dalam akad yang baru untuk menggantikan obyek akad yang lama.

2) Novasi Subyektif Pasif

Merupakan nasabah yang diganti oleh nasabah lain, terjadinya hal tersebut melalui dua cara, yaitu expromissie dan delegatie. Expromissie adalah dimana nasabah lama diganti oleh nasabah baru atas inisiatif BSM (selaku kreditur). Sedangkan delegatie adalah dimana kedudukan nasabah lama digantikan dengan nasabah baru atas inisiatif nasabah lama. Untuk terjadinya novasi tersebut BSM harus secara tegas memberikan persetujuannya dan membebaskan nasabah lama dari keterikatannya untuk melakukan pelunasan pembiayaan.

b. Kompensasi

Cara untuk dihapusnya sebuah perikatan, dimana dari masingmasing kedua belah pihak bertindak sebagai debitur satu terhadap yang lain dan kompensasi tersebut terjadi demi hukum tanpa perlu adanya pernyataan dari para pihak.

c. Likuidasi

Pendapatan yang diterima bank dari hasil penjualan agunan, hal tersebut dilakukan sebagai upaya untuk melunasi seluruh kewajiban nasabah kepada pihak bank, bisa dilakukan oleh pemilik barang agunan atau oleh nasabah tersebut dengan persetujuan yang bersangkutan atau oleh pemilik barang agunan dengan persetujuan dan dibawah pengawasan BSM. Yang didalamnya dapat menggunakan dua cara, yaitu:

1) Penjualan agunan

Penjualan agunan secara dibawah tangan dan penjualan agunan secara lelang baik dilakukan melalui cara lelang sukarela ataupun lelang eksekusi.

2) Penebusan agunan

Pencairan atau penarikan agunan pembiayaan yang dapat dilakukan nasabah ataupun ahli waris pemilik agunan (bukan nasabah) dalam rangka penyelesaian pembiayaan, dengan cara membayarkan kewajiban nasabah yang besaran nominalnya ditetapkan oleh pihak bank.

\section{d. Subrogasi}

Perpindahan hak bank kepada pihak ketiga karena adanya pembayaran kewajiban nasabah kepada bank.

e. Pengadilan

Cara penyelesaian pembiayaan bermasalah terhadap nasabah yang 
sudah tidak memiliki potensi usaha dan itikad baik untuk menyelesaikan kewajibannya. Dimana dalam penyelesaian pembiayaan dilakukan dengan cara penyelesaian melalui pengadilan negeri dengan cara gugatan, eksekusi grosse akta pengakuan hutang, somasi, eksekusi sertifikat hak tanggungan, dan eksekusi sertifikat jaminan fidusia. Tetapi hal memungkinkan yang paling dapat dilakukan oleh bank yaitu melalui cara somasi, eksekusi SHT dan sertifikat jaminan fidusia.

f. Arbitrase dan Alternatif Penyelesaian Sengketa

Cara yang ditempuh bank diluar peradilan hukum atau pengadilan, dimana penyelesaian pembiayaan bermasalah ini dilakukan secara tertulis oleh para pihak baik sebelum timbulnya sengketa ataupun setelah sengketa, dalam kata lain cara ini dapat disebut penyelesaian masalah dengan cara kekeluargaan.

\section{KESIMPULAN DAN IMPLIKASI}

Berdasarkan penelitian yang telah dilakukan di Bank Syariah Mandiri Pusat mengenai Peran Serta dan Mekanisme Bank Syariah pada Pembiayana Sindikasi, maka dapat disimpulkan bahwa:

1. Sindikasi pada BSM sudah diterapkan sejak tahun 2005 melalui sektor korporasi dan ikut serta dalam bersindikasi, sehingga bank syariah dapat berperan aktif dalam pembangunan nasional di Indonesia, serta dapat meningkatkan kepercayaan masyarakat kepada lembaga keuangan syariah dan dapat menarik para investor dalam berpartisipasi pada perkembangan keuangan syariah di Indonesia.
2. Mekanisme sindikasi yang dilakukan BSM mengacu pada Standar Operasional Prosedur Bisnis (SOPB) Pembiayaan Korporasi yang sudah berlaku sejak tahun 2012 dan Overview Pembiayaan Sindikasi bagi BSM, dengan membiayai tiga sektor korporasi yaitu untuk pembiayaan investasi, modal kerja dan pembiayaan infrastruktur. Dalam sindikasi proses analisa mendalam sehingga proses pencairannya dibutuhkan waktu paling sedikit enam bulan, karena proses analisa dilakukan oleh dua bagian yaitu bagian unit bisnis dan komite pembiayaan dan direksi.

Penulis menyadari bahwa masih terdapat keterbatasan di dalam penelitian ini. Sehingga penelitian ini diharapkan mampu memberikan informasi dan masukkan bagi penulis ataupun pihak-pihak yang berkepentingan, yaitu:

1. Bagi Bank Syariah Mandiri

a. BSM harus lebih meningkatkan ketelitian dalam menilai kapasitas calon nasabah serta perusahaan calon nasabah agar dana yang disalurkan oleh bank dapat kembali sesuai dengan kesepakatan antara bank dengan nasabah.

b. Pembinaan dan pengawasan harus dilakukan secara jelas dan terlaksana dengan baik serta memperhatikan tingkat kolektibilitas pembiayaan sehingga bank dapat menghindari pembiayaan bermasalah yang akan muncul kedepannya.

c. Dalam pembiayaan sindikasi diharapkan BSM mampu lebih aktif dalam berkontribusi pada pembangunan nasional melalui proyek-proyek pemerintah, sehingga dapat meningkatkan 
kredibilitas bank syariah dimata masyarakat dan para investor.

d. BSM tetap harus meningkatkan kinerjanya dalam pembiayan sindikasi tanpa melupakan sektor mikro.

2. Bagi Regulator

Belum terdapat aturan/dasar hukum yang secara khusus mengatur tentang BMPK bagi bank syariah, yang dikeluarkan oleh BI maupun OJK.

\section{DAFTAR PUSTAKA}

Agustianto. (2016). Pembiayaan Sindikasi Syariah Untuk Korporasi. Lembaga Pendidikan dan Pelatihan Perbankan dan Keuangan Syariah

Arethusa, Giovanni. (2016). Tanggung Jawab Debitur Terhadap Kreditur Dalam Pembiayaan Proyek Yang Sifatnya Sindikasi. Skripsi. Yogyakarta: Universitas Atma jaya.

Ascarya. (2012). Akad dan Produk Bank Syariah, Akad dan Produk Bank Syariah Malaysia dan Indonesia. Edisi Ke Empat. Jakarta: Rajawali

Azizah, Nur. (2009). Tinjauan Hukum Islam Terhadap Ketentuan Pembiayaan Kredit Sindikasi di PT. Bank Muamalat Indonesia, Tbk. Skripsi. Surabaya: Institut Agama Islam Negeri Sunan Ampel.

Firdaus, Jasri. (2014). Pembiayaan Sindikasi Pada Bank Syariah. Diakses dari http://jasrifirdaus.blogspot.co.id/2 014/04/pembiayaan-sindikasipada-bank-syariah.html

Ghoniyah, Nunung. (2012). Pembiayaan Musyarakah Dari Sisi Penawaran pada Perbankan Syariah di Indonesia. Jurnal Ekonomi dan Bisnis. Vol. 11 No. 1
Harmain, Fransiska, Meyske. (2015). Pembebanan Jaminan Dalam Perjanjian Kredit Sindikasi dan Akibat Hukum Terhadap Kredit Macet. Jurnal Lex et Societatis. Vol. 3 No. 1

Hidayat, Taufik. (2011). Buku Pintar Investasi Syariah. Jakarta: Media Kita

Husaini, Achmad dan Suhadak, dan Zakiyah, Ilmi, Farikhah. (2014). Pengendalian Intern pada Prosedur Pembiayaan Musyarakah Untuk Pemberian Modal Kerja. Jurnal Administrasi Bisnis. Vol. 14 No. 1

Idris, Miftah. (2015). Perjanjian Kredit Perbankan Konvensional dan Perbankan Syariah. Jurnal Komunikasi Hukum. Vol. 1 No. 1

Ifada, Noor dan Husni, Rahmady, Liyantanto. (2011). Pembuatan Web Portal Sindikasi Berita Indonesia Dengan Klasifikasi Metode Single Pass Clustering. Prosiding Seminar Nasional Aplikasi Teknologi Informasi (SNATI).

Iska, Syukri. (2012). Sistem Perbankan Syariah di Indonesia dalam Perspektif Fiqih Ekonomi, Asas, Fungsi dan Aturan Perbankan di Indonesia. Yogyakarta: Fajar Media

Iskandar, Agus. (2010). Pembiayaan AlMusyarakah dalam Praktik Perbankan Berdasarkan Prinsip Syariah. Jurnal Pranata Hukum. Vol. 5 No. 1

Karim, A, Iswahjudi. (2005). Kredit Sindikasi. Jakarta: Karim Syah Law Firm

Kasmir. (2013). Bank dan Keuangan Syariah. Jakarta: Rajawali

Yin, Robert K. 2014. Studi Kasus Desain \& Metode. Jakarta: PT Raja Grafindo Persada 